\title{
Response of biofilm-dwelling ciliate communities to enrichment with algae
}

\author{
Denise Früh $^{1,2}$, Helge Norf ${ }^{1,3,4, *}$, Markus Weitere ${ }^{1,3}$ \\ ${ }^{1}$ University of Cologne, Cologne Biocenter, Zoological Institute, Zülpicher Str. 47b, 50674 Cologne, Germany \\ ${ }^{2}$ Senckenberg Research Institute and Natural History Museum, Department of Limnology and Conservation, \\ Clamecystrasse 12, 63571 Gelnhausen, Germany
}

${ }^{3}$ Helmholtz Centre for Environmental Research - UFZ, Department of River Ecology, and ${ }^{4}$ Department of Aquatic Ecosystem Analysis, Brückstr. 3a, 39114 Magdeburg, Germany

\begin{abstract}
The role of benthic versus planktonic algae in shaping semi-natural ciliate biofilms was studied using miniature flow cells fed by a permanent flow of natural field water from the River Rhine, Germany. Increased food availability for the ciliates was achieved either by supplementation with planktonic algae or by artificial illumination (to stimulate benthic algal growth). Manipulation of both resources significantly increased the total abundance of ciliates and caused significant shifts in the structure of the ciliate community. Supplementation with planktonic algae particularly stimulated suspension-feeding Peritrichia, whereas Choreotrichia were reduced, probably due to indirect effects such as competition or interference. Increased density of benthic algae especially stimulated surfacefeeding groups (e.g. Stichotrichia, Nassophorea), causing the establishment of seasonally atypical structures in the ciliate community, as has been observed in late fall. Ciliates generally responded faster to increased resources during the summer, as compared with winter, suggesting that temperature, as well as the availability of resources, has an important role in shaping ciliate biofilms. Our results are among the first that demonstrate the different contributions of planktonic and benthic algae in shaping ciliate biofilms. Furthermore, they accentuate the need for studies with a higher taxonomic resolution when addressing the responses of microbial biofilms to the increased availability of food.
\end{abstract}

KEY WORDS: River biofilm · Benthic ciliates · Bottom-up · Grazing · Periphyton

\section{INTRODUCTION}

Heterotrophic protozoans can occur in high densities within microbial biofilms, where they can alter both the structure and function of bacterial biofilms (Weitere et al. 2005, Wey et al. 2008, Böhme et al. 2009). In terms of biomass, microbial freshwater biofilms are often dominated by ciliates that can form complex communities of many different taxonomic and functional types (Arndt et al. 2003, Parry 2004, Gong et al. 2005). As inhabitants of the sediment-water interface, ciliates can potentially prey on both surface-attached prey (e.g. Weitere et al. 2005, Königs \& Cleven 2007) and suspended prey (e.g. Eisenmann et al. 2001,
Posch et al. 2001, Weitere et al. 2003). While these functionally different ciliates were found to coexist within biofilms (e.g. Franco et al. 1998, Parry 2004, Gong et al. 2005, Primc-Habdija et al. 2005), the contribution of planktonic versus benthic resources in shaping the structure of ciliate biofilms is not clearly understood. Experimental bottom-up manipulations of biofilms in the field are commonly accomplished by the addition of nutrients, which results in rather unspecific stimulation of several microbial groups, such as bacteria, microalgae, and ciliates. For example, the addition of inorganic nutrients to lake mesocosms has been shown to stimulate bacterial, algal, and ciliate biomass (Hillebrand et al. 2002, Wickham et al. 2004). Similarly, 
Greenwood et al. (2007) have shown that wholestream fertilization results in a general increase in microbial activity. However, little is known on how different resources (suspended, and surface-attached pico- and nano-sized particles) contribute to shaping the structure of ciliate biofilms.

Norf et al. (2007) have developed a flow-cell system for growing and experimentally manipulating microbial biofilms under semi-natural conditions. These flow cells are fed by a permanent current of field water that contains both the organisms for biofilm colonization and the suspended resources necessary for biofilm development. Using increments of benthic and planktonic bacteria, it was shown that the addition of planktonic bacteria can strongly stimulate ciliate communities, whereas enhanced growth of benthic bacteria results in the development of grazingresistant filamentous bacteria (Queck et al. 2006, Norf et al. 2009a). Such defense strategies against protozoan grazers are also common in benthic microalgae, e.g. by attaining large cell sizes or by the secretion of an extracellular matrix (Barranguet et al. 2005). Nevertheless, increased bacterial biomass can accelerate biofilm colonization by ciliates and can alter the structure of the ciliate community. However, early and late succession stages within a developing biofilm can clearly differ in their functional composition, i.e. smaller bacterivorous ciliates, such as Hymenostomatia, colonize biofilms earlier than is usually the case with algivorous ciliates such as large Peritrichia and Stichotrichia. This could mean that, while algal supplements probably do not affect early biofilm development, they may influence the structure of the ciliate community in maturing biofilms.

In the present study, the effects of increased densities of suspended and benthic algae on the development of ciliate biofilms were tested using miniature flow cells. We checked for both quantitative and qualitative (i.e. community structure) effects of the increased availability of resources on ciliate biofilms. The experiments were performed repeatedly during different times of the year (i.e. summer, fall and winter), incorporating different background conditions with respect to ambient resource load and water temperature.

\section{MATERIALS AND METHODS}

Study site and facilities. All experiments were conducted aboard the Ecological Rhine Station of the University of Cologne, Germany. This station is a ship that is permanently anchored in the main stream of the River Rhine in Cologne at Rhine-km 684.5, which refers to the distance from Lake Constance, the source of the non-alpine Rhine. The ship contains laboratories equipped with pump systems that continually supply the laboratories with unaltered field water from the River Rhine. The field water contains both the source organisms for biofilm colonization (e.g. unicellular algae, bacteria, heterotrophic flagellates, ciliates) and the suspended resources essential for biofilm development.

Experimental setup. The flow cells used for the experiments were modified from flow cells commonly used in laboratory experiments (e.g. Stoodley \& Warwood 2003), as described by Norf et al. (2007). The flow cells allowed us to examine living biofilm communities by light microscopy and also to control the manipulation under semi-natural conditions without disturbing the biofilms. The inner dimensions of these flow cells are: $40 \times 19 \times 5 \mathrm{~mm}$ (length $\times$ width $\times$ height), enclosing a volume of $3.8 \mathrm{ml}$. The flow cells were fed with a constant flow-through of River Rhine water (1 volume exchange $\mathrm{min}^{-1}$ ) using tube pumps. The ambient temperature of the field water, which was measured constantly with a digital thermometer, was maintained by storing the flow cells in a temperature-controlled pond set up in a fenestrated room that allowed $\sim 1.5 \%$ of the natural light intensity to reach the flow cells.

Two types of resource treatment were applied in order to distinguish between the effects of increased densities of planktonic and benthic algae on the succession of organisms in ciliate biofilms (Fig. 1); in this approach, the experimental manipulation of resources and the culturing of biofilms started simultaneously. The abundances of planktonic bacteria and algae within the field water were determined, by microscopy, from counts of 4',6-diamidino-2-phenylindole (DAPI)-stained and Lugol-fixed samples, respectively. The temperature was measured constantly using a digital thermometer (see Table 1 for data). Each treatment consisted of 4 replicates, except in Expt Pla1, which only consisted of three replicates. In Expt Pla2, one of the four replicates failed.

The first type of manipulation was designed to test the effects of enrichment with planktonic algae (type Pla; Fig. 1a) on the development of the ciliate biofilm at high ambient water temperatures (Expt Pla1, see Table 1) and at low ambient water temperatures (Expt Pla2, see Table 1), i.e. during summer and winter, respectively. For this purpose, a suspension of freezedried green algae (Chlorella sp.) was fed to the flow cells (Pla ENR). The suspension was prepared by suspending $0.5 \mathrm{~g}$ of Chlorella powder in $15 \mathrm{ml}$ particlefree filtered $(0.2 \mu \mathrm{m})$ field water. Algal aggregates were removed by filtering the suspension through a $20 \mu \mathrm{m}$ filter cartridge. The algal cells in the resulting filtrate had a mean diameter of $5 \mu \mathrm{m}$. A cell density of $3 \times 10^{6}$ cells $\mathrm{ml}^{-1}$ was obtained by diluting the algal suspension with particle-free field water. The algal suspension was added to the flow cells through silicone 
hoses (not shown). Because the ratio of algal suspension to field water was 1:100, the final concentration of supplemented algae was $3 \times 10^{4}$ cells ml ${ }^{-1}$ in the flow cells. As a control, an equal amount $\left(0.04 \mathrm{ml} \mathrm{min}^{-1}\right)$ of algal suspension was filtered through a $1.2 \mu \mathrm{m}$ filter cartridge (in order to remove all suspended algal cells) and fed to the flow cells (hereafter: Pla CON); this treatment was designed to check for possible effects of bacteria that developed within the suspension and of dissolved organic matter (DOM) leaching from the dead algal cells that could potentially enhance bacterial growth within the flow cells.

The second type of resource manipulation was designed to investigate the effects of an increased density of benthic algae (type Ben; Fig. 1b) on the development of ciliate biofilms at moderate water temperatures (Expt Ben1, Table 1) and at low water temperatures (Expt Ben2, Table 1), i.e. during fall and winter, respectively. For this purpose, the flow cells were stored in a temperature-controlled pond (adjusted to ambient water temperature) that also included artificial illumination devices (light intensity: 33 umol photons $\mathrm{m}^{-2} \mathrm{~s}^{-1}$ ) with a light:dark cycle of 12:12 h (hereafter: Ben LIGHT). Treatments run in complete darkness, but with otherwise unaltered ambient conditions (hereafter: Ben DARK), served as a direct control of the Ben LIGHT treatments.

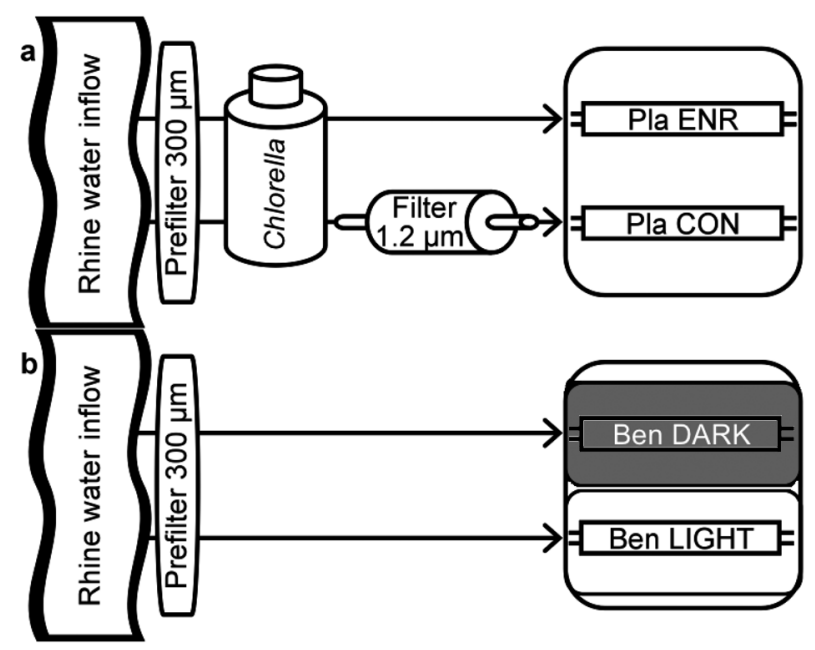

Fig. 1. Experimental setups (schematic). (a) Type Pla, i.e. an approach designed to test the effects of the supplementation of planktonic algae (Chlorella sp.) on the development of biofilm-dwelling ciliate communities. Pla ENR = flow cells enriched with Chlorella suspension; Pla CON = control for Pla ENR, flow cells fed with algae-free filtrate $(1.2 \mu \mathrm{m})$ of the suspension. (b) Type Ben, i.e. an approach designed to test the influence of light-stimulated growth of benthic algae on the development of biofilm-dwelling ciliate communities. Ben LIGHT: illuminated flow cells containing otherwise untreated field water from the River Rhine; Ben DARK: flow cells in complete darkness containing otherwise untreated field water
Expts Ben2 and Pla2 were conducted simultaneously and were thus under the same ambient conditions.

Analysis of ciliate biofilms by microscopy. The ciliate biofilms cultivated within the flow cells were analyzed by putting the flow cells directly onto the cross table of a Zeiss Axioskop light microscope equipped with phase contrast. The first survey was performed $24 \mathrm{~h}$ after starting the experiments and was repeated every 1 to $3 \mathrm{~d}$ until the end of the experiments (Pla1:

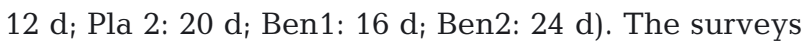
comprised both quantitative (abundance) and qualitative (i.e. species composition) analyses. The structure of the ciliate community was documented by video recordings for later identification of species not instantly recognized. Ciliates were quantified at a magnification of 100 to $200 \times$ (up to $1000 \times$ for identification of species) in defined areas that were randomly distributed over the complete biofilm surface area using an eyepiece grid. At least 60 ciliates per flow cell were recorded. Ciliates were identified using general identification keys (Foissner et al. 1991, 1992, 1994, 1995, Foissner \& Berger 1996), following the classification scheme of Adl et al. (2005). Heterotrophic flagellates (HFs) were quantified in all experiments, and surface-attached microalgae were quantified in both Ben experiments, following the same procedure as applied to the ciliates. The abundances of the HFs were tracked because they could be (1) indicators for indirect effects of resources, due to stimulated bacterial growth, and (2) a potential food source for particular ciliates.

Statistical analyses. Statistical analyses were performed with SPSS 15.0 for Windows. For quantitative comparisons between the treatments, repeated measures ANOVAs (rmANOVAs) were calculated using 'time' as the inner-subject factor and 'treatment' (i.e. resource enrichment) as the between-subject factor. Using rmANOVAs, the effects of increased availability of resources on both the total ciliate abundance and the abundance of particular taxonomic units (fourth to fifth rank) of the ciliates were tested. The first days of biofilm succession, during which only very low numbers of ciliates were observed (Expt Pla1: Days 1 to 3; Expt Ben1: Days 1 to 4; Expts Pla2 and Ben2: Days 1 to 7 ), were excluded from the calculations in order to reduce noise from the observation data. Furthermore, we considered only those taxonomic units that contributed at least $10 \%$ of the total ciliate abundance in any of the treatments during the whole experiment. All data were log-transformed in order to achieve homogeneous variances. In the case of multiple comparisons, the Dunn-Sidak correction method was applied in order to control the familywise Type I error rate.

The effects of the availability of resources on the structure of the ciliate communities were analyzed by 
calculating the Bray-Curtis similarity index (Bray \& Curtis 1957) for the final day of the experiments using Primer 6.0 software (Primer-E). Data were squareroot-transformed in order to reduce the probability of artifacts due to highly dominant ciliate groups. The similarity indices obtained were plotted 2-dimensionally using non-metric, multi-dimensional scaling (NMDS). Significant differences in the structures of the ciliate community between all replicates were determined by cluster analyses using a group average algorithm and adjacent SIMPROF test $(\alpha<0.05)$ and were indicated graphically in the NMDS plots.

\section{RESULTS}

\section{Water temperatures and planktonic abundances of microbes}

Mean water temperatures in the River Rhine were 20, 15 , and $8^{\circ} \mathrm{C}$ during Expts Pla1 (summer), Ben1 (fall) and Pla2/Ben2 (winter), respectively (Table 1). Plankton densities, and thus the availability of natural resources for the developing ciliate biofilms, showed large variations with respect to the date of the experiment. In summer (Expt Pla1), the abundances of planktonic algae $\left(420 \pm 110\right.$ cells ml $\left.{ }^{-1}\right)$ and bacteria $(1.6 \pm 0.2$ $\times 10^{6}$ cells ml $^{-1}$ ) were highest (Table 1). In Expts Ben1 and Pla2/Ben2, the abundances of planktonic algae were $180 \pm 20$ and $150 \pm 20$ cells $\mathrm{ml}^{-1}$, respectively. Planktonic bacteria showed values of $1.1 \pm 0.1 \times 10^{6}$ (Ben1) and $1.4 \pm 0.2 \times 10^{6}$ cells ml $^{-1}$, respectively.

The abundance of HFs was tracked in all experiments. However, neither stimulation of benthic algae (Ben LIGHT) nor supplementation with planktonic algae (Pla ENR) showed significant effects on the abundance of the HFs (Fig. 2; resource effects in rmANOVA: Expt Pla1, $\mathrm{p}=0.976$; Expt Pla2, $\mathrm{p}=0.856$; Expt Ben 1, $\mathrm{p}=0.536$; Expt Ben2, $\mathrm{p}=0.856$ ).

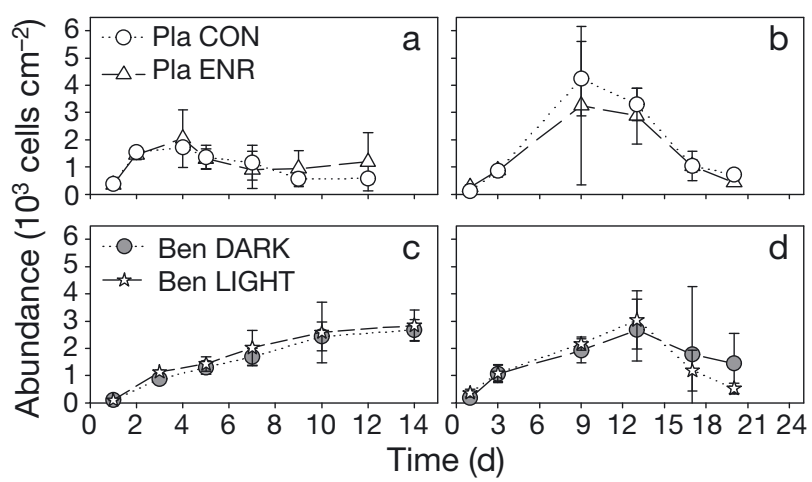

Fig. 2. Effects of supplemented planktonic algae and lightstimulated growth of benthic algae on the abundance of heterotrophic flagellates (HFs). $(a, b)$ Mean $( \pm S D)$ abundance of HFs in flow cells supplemented with suspended algae (Pla ENR) or a filtered (pore size $1.2 \mu \mathrm{m}$ ) algae-free extract of the algal suspension (Pla CON) in Expts (a) Pla1 (carried out at a high temperature) and (b) Pla2 (carried out at a low temperature). (c,d) Mean $( \pm \mathrm{SD})$ abundance of HFs in flow cells with increased light intensity (Ben LIGHT) or kept in darkness (Ben DARK) in Expts (c) Ben1 (moderate temperature) and (d) Ben2 (low temperature). See Fig. 1 and Table 1 for details on experiments and treatments

\section{Effects of supplemented planktonic algae on ciliate biofilm development}

Supplementation of planktonic algae (Pla ENR) consistently resulted in a highly significant stimulation of ciliates in both experiments (Fig. 3a,e, Table 2). However, the magnitude of responses clearly differed with respect to the dates of the experiments; while the total ciliate abundances in Pla CON and Pla ENR were already divergent after $7 \mathrm{~d}$ of succession (Fig. 3a) in Expt Pla1 (performed at higher water temperatures), ciliate abundances in Expt Pla2 (performed at lower water temperatures) were not different within the treatments until Day 10 (Fig. 3e). Furthermore, the maximum ciliate abundance was 9 times higher in Expt Pla1 on

Table 1. Overview of experiments, including time periods as well as water temperature and plankton abundance observed in the field water from the River Rhine. Plankton data are means \pm SD. Temperature data are means of daily averages (range in parentheses). See Fig. 1 for details on treatments

\begin{tabular}{|c|c|c|c|c|c|}
\hline \multirow[t]{2}{*}{ Expt } & \multirow[t]{2}{*}{ Treatment } & \multirow{2}{*}{$\begin{array}{l}\text { Time period } \\
\text { (dd/mm/yy) }\end{array}$} & \multirow{2}{*}{$\begin{array}{l}\text { Temp. } \\
\left({ }^{\circ} \mathrm{C}\right)\end{array}$} & \multicolumn{2}{|c|}{ Plankton abundance (cells $\mathrm{ml}^{-1}$ ) } \\
\hline & & & & Bacteria & Algae \\
\hline Pla1 & $\begin{array}{l}\text { Pla ENR } \\
\text { Pla CON }\end{array}$ & $22 / 08 / 07$ to $05 / 09 / 07$ & $20(18-21)$ & $1.6 \pm 0.2 \times 10^{6}$ & $420 \pm 110$ \\
\hline Ben1 & $\begin{array}{l}\text { Ben LIGHT } \\
\text { Ben DARK }\end{array}$ & 08/10/07 to $24 / 10 / 07$ & $15(12-17)$ & $1.1 \pm 0.1 \times 10^{6}$ & $180 \pm 20$ \\
\hline Pla2 & $\begin{array}{l}\text { Pla ENR } \\
\text { Pla CON }\end{array}$ & $14 / 11 / 07$ to $10 / 12 / 07$ & $8(7-9)$ & $1.4 \pm 0.2 \times 10^{6}$ & $150 \pm 20$ \\
\hline Ben2 & $\begin{array}{l}\text { Ben LIGHT } \\
\text { Ben DARK }\end{array}$ & $14 / 11 / 07$ to $10 / 12 / 07$ & $8(7-9)$ & $1.4 \pm 0.2 \times 10^{6}$ & $150 \pm 20$ \\
\hline
\end{tabular}


Day $9\left(60 \pm 25\right.$ ind. $\mathrm{cm}^{-2}$ in Pla CON and $550 \pm 190$ ind. $\mathrm{cm}^{-2}$ in Pla ENR; Fig. 3a) and only 5 times higher in Expt Pla2 on Day 17 (140 \pm 15 ind. $\mathrm{cm}^{-2}$ in Pla CON and $720 \pm 140$ in Pla ENR; Fig. 3e) in Pla ENR compared to Pla CON.

Regarding the taxonomic composition, the strongest effects were detected for Peritrichia, which were significantly stimulated by Chlorella sp. (Pla ENR) in both experiments (Table 2). In Expt Pla1, they made up $20 \%$ of the total ciliate abundance in Pla CON (Fig. 3b) and $71 \%$ in Pla ENR (Fig. 3c) on Day 12. In Expt Pla2, the proportion of Peritrichia was higher than in Expt Pla1 $65 \%$ in Pla CON and $80 \%$ in Pla ENR on Day 20; Fig. $3 f, g)$. Opposite observations were made for Choreotrichia, the abundance of

Fig. 3. Results of (a-d) Expts Pla1 (August to September 2007) and (e-h) Pla2 (November to December 2007) on the effects of supplemented planktonic algae on the early development of biofilm-dwelling ciliate communities. $(\mathrm{a}, \mathrm{e})$ Development of the mean $( \pm \mathrm{SD})$ ciliate abundances in the treatment with a supplement of planktonic algae (Pla ENR) or a supplement of filtered $(1.2 \mu \mathrm{m})$, algae-free algal suspension (Pla CON). (b,f) Taxonomic composition (as percent contribution of ciliate groups to total ciliate abundance) of the ciliate community in Pla CON. (c,g) Taxonomic composition of the ciliate community in Pla ENR. $(\mathrm{d}, \mathrm{h})$ Non-metric multidimensional scaling (NMDS) based on the Bray-Curtis similarity of all replicates per treatment. Significantly different clusters identified using a SIMPROF test are encircled. See Fig. 1, Table 1 for details on experiment and treatments
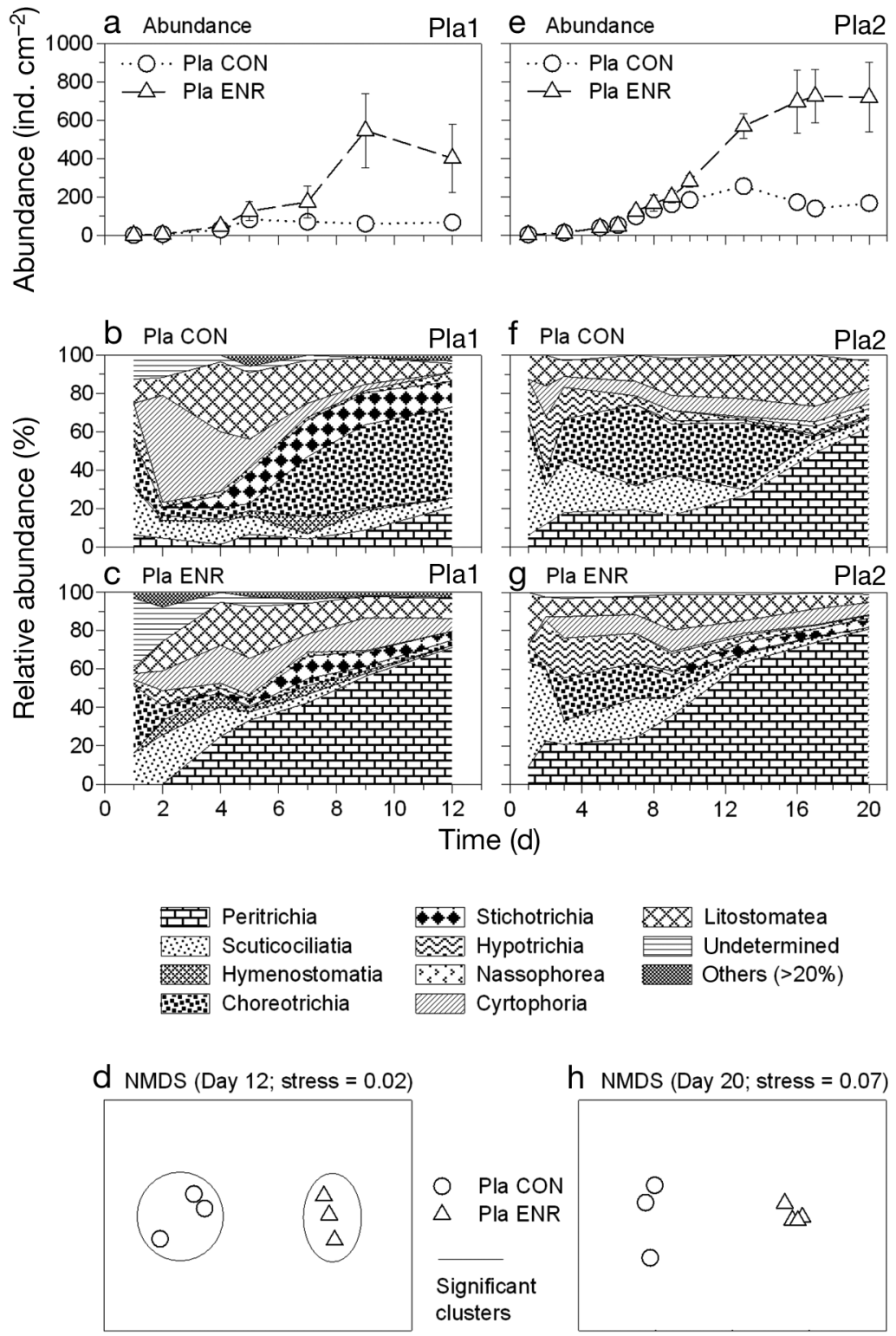

Table 2. Results of the repeated measures ANOVAs (rmANOVAs) calculated to test the effects of supplements of planktonic algae and of light-stimulated benthic algal growth on the development of the total ciliate abundance and on the abundance of ciliate taxonomic units. Only those units that showed significant effects from the resources, with subsequent Dunn-Sidak correction, are listed. No taxonomic group showed significant effects of the treatment in Expt Ben1. Only the results of betweensubject factors (resources) are given. See Fig. 1, Table 1 for details on treatments. ${ }^{*} \mathrm{p}<0.05,{ }^{* *} \mathrm{p}<0.01,{ }^{* * *} \mathrm{p}<0.001$

\begin{tabular}{|c|c|c|c|c|}
\hline \multirow[t]{2}{*}{ Expt } & \multirow[t]{2}{*}{ Treatment } & \multirow{2}{*}{$\begin{array}{l}\text { Total abundance } \\
\text { Fratio and df }\end{array}$} & \multicolumn{2}{|c|}{ Abundance of taxonomic ciliate groups } \\
\hline & & & Taxonomic ciliate units & $F$ ratio and df \\
\hline Pla1 & $\begin{array}{l}\text { Pla ENR } \\
\text { Pla CON }\end{array}$ & $F_{1,4}=35.95^{* *}$ & $\begin{array}{c}\text { Peritrichia } \\
\text { Hymenostomatia }\end{array}$ & $\begin{array}{c}F_{1,4}=206.8^{* * *} \\
F_{1,4}=31.8^{*}\end{array}$ \\
\hline Ben1 & $\begin{array}{l}\text { Ben LIGHT } \\
\text { Ben DARK }\end{array}$ & $F_{1,6}=41.60^{* * *}$ & - & - \\
\hline Pla2 & $\begin{array}{l}\text { Pla ENR } \\
\text { Pla CON }\end{array}$ & $F_{1,5}=319.72^{* * *}$ & $\begin{array}{l}\text { Choreotrichia } \\
\text { Peritrichia }\end{array}$ & $\begin{array}{c}F_{1,5}=18.3^{*} \\
F_{1,5}=56.5^{* *}\end{array}$ \\
\hline Ben2 & $\begin{array}{l}\text { Ben LIGHT } \\
\text { Ben DARK }\end{array}$ & $F_{1,6}=10.87^{*}$ & $\begin{array}{l}\text { Nassophorea } \\
\text { Stichotrichia }\end{array}$ & $\begin{aligned} F_{1,6} & =17.5^{*} \\
F_{1,6} & =43.6^{* *}\end{aligned}$ \\
\hline
\end{tabular}


which was reduced in Pla ENR (significant for Expt Pla2; Table 2); they contributed $45 \%$ of the ciliate communities in Pla CON and 5\% in Pla ENR on Day 12 of Expt Pla1 (Fig. 3b,c). In Expt Pla2, they contributed a maximum of $40 \%$ in Pla CON and $20 \%$ in Pla ENR (Fig. 3f,g). The NMDS plots of the Bray-Curtis similarity, which were calculated for the last day of each experiment (Day 12 for Expt Pla1 and Day 20 for Expt Pla2), consistently showed clear separation between the ciliate communities in the Pla CON and Pla ENR treatments (Fig. 3d,h). This separation was significant (SIMPROF test, $\alpha<0.05$ ) for Expt Pla1. See Appendix 1 (Table A1) for ciliate morphotypes observed in the present study.
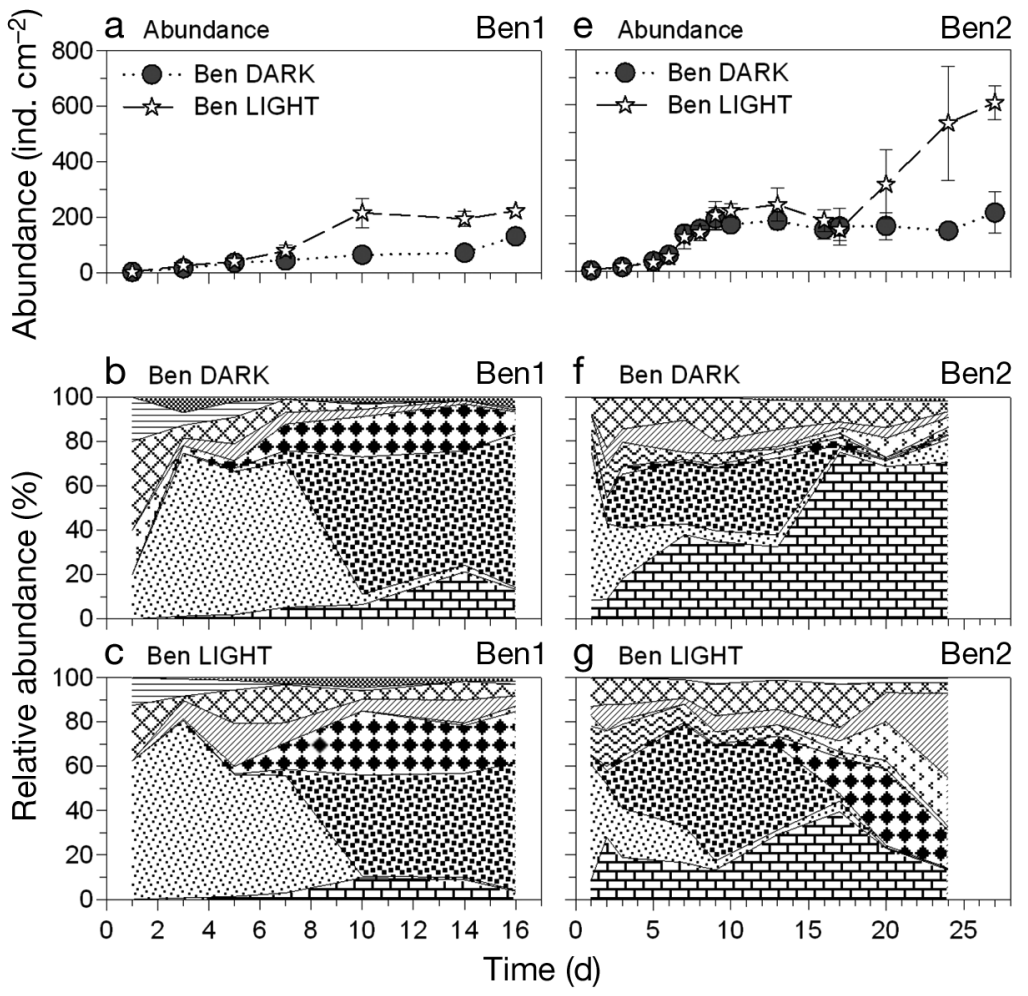

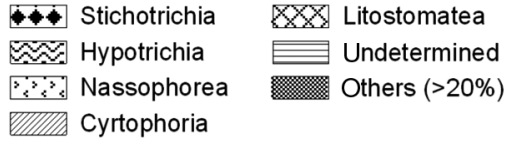

d NMDS (Day 16; stress $=0.02$

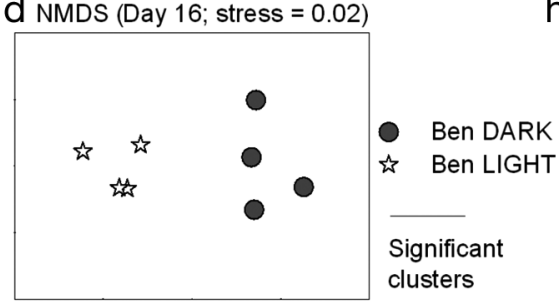

h NMDS (Day 25; stress $=0.02$

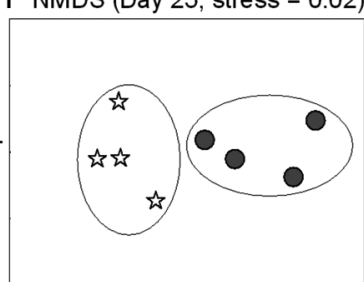

Fig. 4. Results of Expts (a-d) Ben1 (October 2007) and (e-h) Ben2 (November to December 2007) on the effects of light-stimulated benthic algae on early biofilm-dwelling ciliate communities. $(a, e)$ Development of the mean $( \pm$ SD) ciliate abundance with elevated light exposure (Ben LIGHT) and the dark control (Ben DARK). (b,f) Taxonomic composition of the ciliate community in Ben DARK, given as contribution of ciliate groups to total ciliate abundance, and $(\mathrm{c}, \mathrm{g})$ in Ben LIGHT. $(\mathrm{d}, \mathrm{h})$ Non-metric multidimensional scaling (NMDS) based on the Bray-Curtis similarity of all replicates per treatment. Significantly different clusters identified using a SIMPROF test are encircled. See Fig. 1, Table 1 for details on experiments and treatments
Effects of light-stimulated benthic algal growth on ciliate biofilm development

Artificial illumination (Ben LIGHT) resulted in strong stimulation of surface-attached microalgae, especially the species of unicellular and filamentous diatoms. In Expt Ben1, the abundance of benthic algae in Ben DARK was rather low (final abundance: $2.0 \pm 4.5$ cells cm${ }^{-2}$ ). In Ben LIGHT, the abundance of benthic algae increased exponentially during the experiment, reaching a maximum of $2750 \pm 1490$ cells $\mathrm{cm}^{-2}$ on Day 14. In Expt Ben2, the final abundance of benthic algae was $1.0 \pm 1.5$ cells cm$~^{-2}$ in Ben DARK and $52700 \pm 13050$ cells $\mathrm{cm}^{-2}$ in Ben LIGHT on Day 24.

Illumination also resulted in significant effects on the total abundance of ciliates in Expt Ben1 (Fig. 4, Table 2) and on both total abundance and community structure in Expt Ben2 (Fig. 4, Table 2). In Expt Ben1, total abundances of ciliates in Ben LIGHT and Ben DARK were equal until Day 5 (Fig. 4a). In the following days, the abundance of ciliates in Ben DARK increased linearly from $45 \pm 10$ ind. $\mathrm{cm}^{-2}$ on Day 5 to $70 \pm 25$ ind $\mathrm{cm}^{-2}$ on Day 14 (Fig. 4a), whereas in Ben LIGHT we observed an exponential increase to $215 \pm 55$ ind. $\mathrm{cm}^{-2}$ (steady-state abundance) on Day 10.

In Expt Ben2, the total abundances of ciliates in Ben DARK and Ben LIGHT increased in parallel until Day 17 (Fig. 4e), when we recorded $160 \pm 65$ ind $\mathrm{cm}^{-2}$ in Ben DARK and $150 \pm 40$ ind. $\mathrm{cm}^{-2}$ in Ben LIGHT. In the following days, the abundance of ciliates developed completely differently in the 2 treatments. At the end of the experiment (Day 27), the abundance of ciliates was $210 \pm 75$ ind. $\mathrm{cm}^{-2}$ in Ben DARK and $610 \pm 60$ ind. $\mathrm{cm}^{-2}$ in Ben LIGHT.

Regarding taxonomic composition, Ben LIGHT resulted in a selective increase in distinct taxonomic units (Fig. 4b,c,f,g); 
while taxonomic composition did not differ significantly between Ben LIGHT and Ben DARK in Expt Ben1, single taxonomic units were stimulated in Expt Ben 2 (Table 2). Thus, the taxonomic responses observed in Expt Ben2 (performed at lower ambient water temperatures) were different in that Nassophorea and Stichotrichia responded significantly to the stimulation by benthic algae (Table 2, Fig. 4g). Nassophorea increased from Day 17 onwards and contributed $4 \%$ of the total ciliate abundance in Ben DARK and $22 \%$ in Ben LIGHT on Day 24. Stichotrichia, which also showed significant treatment effects, reached at maximum $0.5 \%$ in Ben DARK and $25 \%$ in Ben LIGHT. Peritrichia, which were dominant in the Ben DARK treatment towards the end of the experiment ( 75 and $70 \%$ on Days 17 and 24, respectively), made up only $40 \%$ (Day 17) and 13\% (Day 24) of the total ciliate abundance in the Ben LIGHT treatment. Because the absolute abundances of Peritrichia were similar in the 2 treatments of Expt Ben2, no significant treatment effect could be detected (Table 2). NMDS plots of the Bray-Curtis-similarity, which were calculated for the last days of the experiments, did not reveal significant treatment effects (SIMPROF test $;$ p > 0.05) in Expt Ben1 (Fig. 4d). In Expt Ben2, 2 significant clusters (SIMPROF test; $\alpha<0.05$ ) that separated the Ben LIGHT from the Ben DARK treatment were obtained (Fig. 4h). A list of ciliate morphotypes observed during the present study is given in Appendix 1 (Table A1).

\section{DISCUSSION}

To our knowledge, this is the first study to test the impact of directly increased densities of microalgae on natural ciliate biofilms (but see Hillebrand et al. 2002, Wickham et al. 2004 for fertilization experiments). The high temporal resolution of the community analyses that we performed was facilitated by the application of flow-cell systems: unlike conventional surveys, the flow cells permit documentation of processes that appear in short chronological sequences.

As hypothesized when planning the experiments, early biofilm colonization by ciliates was generally not affected by algal supplements due to the lack of algivorous species that could have been stimulated; conversely, later stages in the succession of ciliates in the biofilm (i.e. maturation) showed clear positive responses to increased availability of both planktonic and benthic algae. This contrasts with the observations made previously by Norf et al. (2009a) in experiments with supplements of planktonic and benthic bacteria in that both early colonization and maturation of ciliate biofilms was stimulated by the bacterial supplements. Taken together, these results confirm earlier assump- tions on the functional succession of surface-dwelling ciliates (cf. Franco et al. 1998).

Remarkable differences in the responses to algal supplements were also observed between the seasonal experiments - probably due to differences in water temperature. It is well understood that several metabolic processes, such as feeding and growth rates, are controlled by temperature (Montagnes \& Weisse 2000, Weisse et al. 2002). Norf \& Weitere (2010) have shown that both temperature and the availability of planktonic bacteria are important factors controlling the development of ciliate biofilms. Our data confirm these results in that the ciliate communities responded much more slowly to increased food availability at lower, compared with higher, water temperatures.

\section{Enrichment with planktonic algae affects ciliate abundance and biofilm structure}

By far the strongest effects on ciliate abundance were detected in the experiments with supplements of planktonic algae. The stimulation of Peritrichia, in particular, demonstrates a strong direct benefit for these suspension-feeding ciliates (cf. Eisenmann et al. 2001, Kathol et al. 2009) from the enrichment with suspended algae. The increase in Peritrichia was accompanied by a reduction in suspension-feeding Choreotrichia (exclusively Tintinnidium sp. and Strobilidium caudatum) in both experiments because both groups occupy similar functional niches. Norf et al. (2009a) obtained similar results for enrichment with planktonic bacteria. A likely explanation is that Peritrichia, most of which have stalked cell bodies, could potentially graze upon particles in higher layers of the water column. This could result in a limitation of resources in the lower biofilm layers and, consequently, cause a decrease in other suspension-feeding ciliates such as Choreotrichia. Such a competitive advantage of Peritrichia, compared to other suspension-feeding ciliates, could explain the dominance of Peritrichia in most mature ciliate biofilms (Gong et al. 2005, Primc-Habdija et al. 2005, Norf et al. 2009b, Kathol et al. 2011).

In addition to the clear and highly significant effects of Pla ENR on suspension-feeding ciliates (see above), significant effects were also observed for surfacebrowsing groups such as Hymenostomatia. In our case, Glaucoma scintillans and Lembadion lucens showed positive responses to supplementation with planktonic algae. We suspect that the bacterivorous G. scintillans was most likely stimulated by enhanced growth of biofilm bacteria (cf. Huws et al. 2005, Weitere et al. 2005), whereas the positive response of the (mostly predatory) L. lucens could have resulted from an increase in smaller bacterivorous microbes such as 
HFs and small ciliates. Especially the grazing of $L$. lucens upon HFs could explain why no significant effects of Pla ENR on HFs were detected. However, it is remarkable that stimulation of bacterivorous ciliates was observed only in the Pla ENR treatments, which presumably contained the same amount of DOM as the control treatments. We suspect that enhanced activity of suspension feeders and, consequently, increased release of metabolites (including DOM) near the biofilm surface could stimulate benthic bacterial production (cf. Zubkov \& Sleigh 1999). It should be noted that even stalked Peritrichia can occur within the bacterial biofilm matrix, as has been recently shown with laser-scanning microscopy (Villanueva et al. 2011). In this way, even planktivorous Peritrichia could make DOM available for the biofilm food web.

\section{Direct and indirect effects of benthic algae on surface-feeding ciliates}

Towards the end of the experiments with artificial illumination (Ben LIGHT), we observed both a significant increase in ciliate abundance and an accumulation of filamentous algae. However, ciliates reached steady-state abundances after 12 to $15 \mathrm{~d}$ of biofilm development in Expt Ben1, while benthic microalgae continued increasing until the end of the experiment. It is likely that most algal cells within the maturing biofilms were resistant to grazing, e.g. by secretion of extracellular polymeric substances (EPS) or by the formation of grazing-resistant morphotypes (e.g. large cell chains in Melosira sp.). In fact, the majority of microalgae in the mature biofilms were filamentous. On this account, Barranguet et al. (2005) reported that the presence of grazers increases the density of grazing-resistant algae in biofilms. Yet another possible explanation is that the ciliates had reached carrying capacity due to space limitation. However, we do not favor this explanation because remarkably higher densities of ciliates were previously reported in similar experiments (Norf et al. 2007, 2009a).

Regarding ciliates, artificial illumination - and thus enhanced growth of benthic algae-results in an increase particularly in benthivorous taxa, as was expected when planning the experiments. In Expt Ben2, performed during the fall, Nassophorea and Stichotrichia, in particular, were positively affected; both of these groups usually occur during seasons of phytoplankton and phytobenthos blooms (spring and late summer). In Expt Ben2, the stimulation of Stichotrichia resulted in the formation of a ciliate community that is rather atypical for this time of the year (i.e. fall) in the River Rhine (cf. Norf et al. 2009b).
Besides the direct consumption of algae by surfacebrowsing ciliates (e.g. Chilodontopsis depressa, Chilodonella uncinata), selected ciliates could also benefit from stimulated benthic bacterial growth, e.g. due the release of algal exudates (Grossart \& Simon 2007). Goedkoop et al. (1997) showed that supplementation with diatoms can stimulate both the activity and biomass of bacteria and subsequently increase the abundance of ciliates. In the present study, indications for such indirect effects of light-stimulated algal growth are rendered from the stimulation of bacterivorous ciliates such as Hexotricha caudata (Nassophorea) and Cinetochilum margaritaceum (Hymenostomatia). As mentioned above, we detected no effects of Ben LIGHT on HFs; this could be due to rapid trophic transfer of DOM via bacteria and HFs to ciliates. On this account, Norf et al. (2009a) reported that supplementation with dissolved organic carbon in developing biofilms can lead to (temporary, visible) stimulation of HFs that are immediately grazed by ciliates. Another likely explanation is that the maturing bacterial biofilms were resistant to grazing by HFs but were not resistant to grazing by ciliates (cf. Weitere et al. 2005).

\section{Conclusion on the position of ciliates in the biofilm food web}

There is full awareness of the significant role of ciliates in linking primary production to higher trophic levels within planktonic food webs (e.g. Azam et al. 1983). However, in biofilm food webs the role of protozoans is apparently underestimated. The current understanding of benthic food webs is that the primary production on surfaces is predominantly consumed by the grazing macrofauna (cf. Wetzel 2001). The present study shows that parts of the autotrophic primary production are utilized by the microfauna, as well. Consumption of planktonic and benthic algae by ciliates represents 2 different energy channels through which primary production enters the biofilm consumer food web.

Both of the experimental resource increments resulted in both significant increases in total ciliate abundance and significant community effects. Both variables can also have severe influences on the energy flow within microbial food webs. Further investigations are needed to help disentangle the quantitative importance of ciliates in benthic food webs.

Acknowledgements. We thank the German Research Foundation (DFG, project WE 3545/3-1) for funding, and F. Bartlett and A. Kaus (Helmholtz Centre for Environmental Research-UFZ) for critical comments and linguistic improvements. M. Kathol (University of Cologne) kindly provided data on planktonic algal and bacterial abundances in the River Rhine. 


\section{LITERATURE CITED}

Adl SM, Simpson AGB, Farmer MA, Andersen RA and others (2005) The new higher level classification of eukaryotes with emphasis on the taxonomy of protists. J Eukaryot Microbiol 52:399-451

Arndt H, Schmidt-Denter K, Auer B, Weitere M (2003) Protozoans and biofilms. In: Krumbein WE, Paterson DM, Zavarzin GA (eds) Fossil and recent biofilms, mats and networks. Kluwer Academic Publishers, Dordrecht, p 173-189

Azam F, Fenchel T, Field JG, Gray JS, Meyer-Reil LA, Thingstad F (1983) The ecological role of water-column microbes in the sea. Mar Ecol Prog Ser 10:257-263

Barranguet C, Veuger B, Van Beusekom SAM, Marvan P, Sinke JJ, Admiraal W (2005) Divergent composition of algal-bacterial biofilms developing under various external factors. Eur J Phycol 40:1-8

Böhme A, Risse-Buhl U, Küsel K (2009) Protists with different feeding modes change biofilm morphology. FEMS Microbiol Ecol 69:158-169

Bray JR, Curtis JT (1957) An ordination of the upland forest communities of Southern Wisconsin. Ecol Monogr 27:325349

Eisenmann H, Letsiou I, Feuchtinger A, Beisker W, Mannweiler E, Hutzler P, Arnz P (2001) Interception of small particles by flocculent structures, sessile ciliates, and the basic layer of a wastewater biofilm. Appl Environ Microbiol 67:4286-4292

Foissner W, Berger H (1996) A user-friendly guide to the ciliates (Protozoa, Ciliophora) commonly used by hydrobiologists as bioindicators in rivers, lakes, and waste waters, with notes on their ecology. Freshw Biol 35:375-482

Foissner W, Blatterer H, Berger H, Kohmann F (1991) Taxonomische und ökologische Revision der Ciliaten des Saprobiensystems, Band I. Cyrtophorida, Oligotrichida, Hypotrichia, Colpodea. Informationsber Bayer Landesamt Wasserwirtsch, Heft 1/91. Bayerisches Landesamt für Wasserwirtschaft, Deggendorf

Foissner W, Blatterer H, Kohmann F (1992) Taxonomische und ökologische Revision der Ciliaten des Saprobiensystems, Band II. Peritrichia, Heterotrichida, Odontostomatida. Informationsber Bayer Landesamt Wasserwirtsch, Heft 5/92. Bayerisches Landesamt für Wasserwirtschaft, Deggendorf

Foissner W, Blatterer H, Kohmann F (1994) Taxonomische und ökologische Revision der Ciliaten des Saprobiensystems, Band III. Hymenostomata, Prostomatida, Nassulida. Informationsber Bayer Landesamt Wasserwirtsch, Heft 1/94. Bayerisches Landesamt für Wasserwirtschaft, Deggendorf

Foissner W, Berger H, Blatterer H, Kohmann F (1995) Taxonomische und ökologische Revision der Ciliaten des Saprobiensystems, Band IV. Gymnostomatea, Loxodes, Suctoria. Informationsber Bayer Landesamt Wasserwirtsch, Heft 1. Bayerisches Landesamt für Wasserwirtschaft, Deggendorf

Franco C, Esteban GF, Tellez C (1998) Colonization and succession of ciliated protozoa associated with submerged leaves in a river. Limnologica 28:275-283

Goedkoop W, Gullberg KR, Johnson RK, Ahlgren I (1997) Microbial response of a freshwater benthic community to a simulated diatom sedimentation event: interactive effects of benthic fauna. Microb Ecol 34:131-143

> Gong J, Song WB, Warren A (2005) Periphytic ciliate colonization: annual cycle and responses to environmental conditions. Aquat Microb Ecol 39:159-170

Greenwood JL, Rosemond AD, Wallace JB, Cross WF, Weyers
HS (2007) Nutrients stimulate leaf breakdown rates and detritivore biomass: bottom-up effects via heterotrophic pathways. Oecologia 151:637-649

Grossart HP, Simon M (2007) Interactions of planktonic algae and bacteria: effects on algal growth and organic matter dynamics. Aquat Microb Ecol 47:163-176

Hillebrand H, Kahlert M, Haglund AL, Berninger UG, Nagel S, Wickham S (2002) Control of microbenthic communities by grazing and nutrient supply. Ecology 83:2205-2219

Huws SA, McBain AJ, Gilbert P (2005) Protozoan grazing and its impact upon population dynamics in biofilm communities. J Appl Microbiol 98:238-244

Kathol M, Norf H, Arndt H, Weitere M (2009) Effects of temperature increase on the grazing of planktonic bacteria by biofilm-dwelling consumers. Aquat Microb Ecol 55:65-79

Kathol M, Fischer H, Weitere M (2011) Contribution of biofilm-dwelling consumers to the pelagic-benthic coupling in a large river. Freshw Biol 56:1160-1172

Königs S, Cleven EJ (2007) The bacterivory of interstitial ciliates in association with bacterial biomass and production in the hyporheic zone of a lowland stream. FEMS Microbiol Ecol 61:54-64

- Montagnes DJS, Weisse T (2000) Fluctuating temperatures affect growth and production rates of planktonic ciliates. Aquat Microb Ecol 21:97-102

Norf H, Weitere M (2010) Resource quantity and seasonal background alter warming effects on communities of biofilm ciliates. FEMS Microbiol Ecol 74:361-370

> Norf H, Arndt H, Weitere M (2007) Impact of local temperature increase on the early development of biofilm-associated ciliate communities. Oecologia 151:341-350

Norf H, Arndt H, Weitere M (2009a) Responses of biofilmdwelling ciliate communities to planktonic and benthic resource enrichment. Microb Ecol 57:687-700

Norf H, Arndt M, Weitere M (2009b) Effects of resource supplements on mature ciliate biofilms: an empirical test using a new type of flow cell. Biofouling 25:769-778

Parry JD (2004) Protozoan grazing of freshwater biofilms. Adv Appl Microbiol 54:167-196

Posch T, Jezbera J, Vrba J, Simek K, Pernthaler J, Andreatta S, Sonntag B (2001) Size selective feeding in Cyclidium glaucoma (Ciliophora, Scuticociliatida) and its effects on bacterial community structure: a study from a continuous cultivation system. Microb Ecol 42:217-227

- Primc-Habdija B, Habdija I, Matonickin R, Spoljar M (2005) Development of ciliate community on artificial substrates associated with vertical gradients of environmental conditions in a karstic lake. Arch Hydrobiol 164:513-527

Queck SY, Weitere M, Moreno AM, Rice SA, Kjelleberg S (2006) The role of quorum sensing mediated developmental traits in the resistance of Serratia marcescens biofilms against protozoan grazing. Environ Microbiol 8: $1017-1025$

Stoodley P, Warwood BK (2003) Use of flow cells and annular reactors to study biofilms. In: Lens $\mathrm{P}, \mathrm{O}^{\prime}$ Flaherty $\mathrm{V}$, Moran A, Stoodley P, Mahony T (eds) Biofilms in industry, medicine and environmental biotechnology - characteristics, analysis and control. IWA Publishing, London

> Villanueva VD, Font J, Schwartz T, Romani AM (2011) Biofilm formation at warming temperature: acceleration of microbial colonization and microbial interactive effects. Biofouling 27:59-71

Weisse T, Stadler P, Lindstrom ES, Kimmance SA, Montagnes DJS (2002) Interactive effect of temperature and food concentration on growth rate: a test case using the small freshwater ciliate Urotricha farcta. Limnol Oceanogr $47: 1447-1455$ 
Weitere M, Schmidt-Denter K, Arndt H (2003) Laboratory experiments on the impact of biofilms on the plankton of a large river. Freshw Biol 48:1983-1992

Weitere M, Bergfeld T, Rice SA, Matz C, Kjelleberg S (2005) Grazing resistance of Pseudomonas aeruginosa biofilms depends on type of protective mechanism, developmental stage and protozoan feeding mode. Environ Microbiol 7:1593-1601

Wetzel RG (2001) Limnology: lake and river ecosystems. Academic Press, San Diego, CA
Wey JK, Scherwass A, Norf H, Arndt H, Weitere M (2008) Effects of protozoan grazing within river biofilms under semi-natural conditions. Aquat Microb Ecol 52: 283-297

Wickham SA, Nagel S, Hillebrand H (2004) Control of epibenthic ciliate communities by grazers and nutrients. Aquat Microb Ecol 35:153-162

Zubkov MV, Sleigh MA (1999) Growth of amoebae and flagellates on bacteria deposited on filters. Microb Ecol 37: $107-115$

Appendix 1. Additional taxonomic data

Table A1. Ciliate morphotypes observed during experiments with supplementation of planktonic algae (Type Pla) and with lightstimulated growth of benthic algae (Type Ben). Pla1 and Pla2 refer to experiments carried out at high and low temperatures, respectively. Ben1 and Ben2 refer to experiments carried out at moderate and low temperatures, respectively. For further details, see Fig. 1 and Table 1

\begin{tabular}{|c|c|c|c|c|c|c|c|c|c|}
\hline \multirow{3}{*}{ Rank } & \multirow{3}{*}{ Morphotypes } & \multirow{2}{*}{\multicolumn{2}{|c|}{$\longrightarrow$ Pla1 }} & \multirow{2}{*}{\multicolumn{4}{|c|}{ Experiments and treatments }} & \multirow{2}{*}{\multicolumn{2}{|c|}{- Ben $2-$}} \\
\hline & & & & & $\mathrm{n} 1-$ & & & & \\
\hline & & $\begin{array}{c}\text { Pla } \\
\text { CON }\end{array}$ & $\begin{array}{l}\text { Pla } \\
\text { ENR }\end{array}$ & $\begin{array}{l}\text { Ben } \\
\text { DARK }\end{array}$ & $\begin{array}{c}\text { Ben } \\
\text { LIGHT }\end{array}$ & $\begin{array}{c}\mathrm{Pla} \\
\mathrm{CON}\end{array}$ & $\begin{array}{l}\text { Pla } \\
\text { ENR }\end{array}$ & $\begin{array}{l}\text { Ben } \\
\text { DARK }\end{array}$ & $\begin{array}{c}\text { Ben } \\
\text { LIGHT }\end{array}$ \\
\hline \multirow[t]{3}{*}{ Choreotrichia } & Strobilidium caudatum & $\mathrm{x}$ & $\mathrm{x}$ & $\mathrm{x}$ & $\mathrm{x}$ & $\mathrm{x}$ & $\mathrm{x}$ & $\mathrm{x}$ & $\mathrm{x}$ \\
\hline & Tintinnidium sp. & $\mathrm{x}$ & $\mathrm{x}$ & $\mathrm{x}$ & $\mathrm{x}$ & $\mathrm{x}$ & $\mathrm{x}$ & $\mathrm{x}$ & $\mathrm{x}$ \\
\hline & Undetermined & & $\mathrm{x}$ & & & & & $\mathrm{x}$ & \\
\hline \multirow[t]{11}{*}{ Cyrtophoria } & Chilodonella uncinata & $\mathrm{x}$ & $\mathrm{x}$ & $\mathrm{x}$ & $\mathrm{x}$ & & $\mathrm{x}$ & $\mathrm{x}$ & \\
\hline & Chilodontopsis depressa & & & & & $\mathrm{x}$ & $\mathrm{x}$ & $\mathrm{x}$ & \\
\hline & Dysteria fluviatilis & & $\mathrm{x}$ & & & & & & \\
\hline & Gastronauta sp. & & $\mathrm{x}$ & & $\mathrm{x}$ & $\mathrm{x}$ & $\mathrm{x}$ & $\mathrm{x}$ & $\mathrm{x}$ \\
\hline & Odontochlamys alpestris & & $\mathrm{x}$ & & & & & & \\
\hline & Pseudochilodonopsis sp. & & $\mathrm{x}$ & & & & $\mathrm{x}$ & & \\
\hline & Thigmogaster oppositevacuolatus & $\mathrm{x}$ & $\mathrm{x}$ & & & & & & \\
\hline & Thigmogaster potamophilus & & $\mathrm{x}$ & & & & & & \\
\hline & Thigmogaster sp. & $\mathrm{x}$ & $\mathrm{x}$ & & & $\mathrm{x}$ & $\mathrm{x}$ & $\mathrm{x}$ & $\mathrm{x}$ \\
\hline & Trochilia minuta & & & & & & $\mathrm{x}$ & & \\
\hline & Undetermined & $\mathrm{x}$ & $\mathrm{x}$ & $\mathrm{x}$ & $\mathrm{x}$ & $\mathrm{x}$ & $\mathrm{x}$ & $\mathrm{x}$ & $\mathrm{x}$ \\
\hline Heterotrichea & Stentor sp. & $\mathrm{x}$ & $\mathrm{x}$ & & $\mathrm{x}$ & & & & $\mathrm{x}$ \\
\hline \multirow[t]{3}{*}{ Hymenostomatia } & Glaucoma scintillans & $\mathrm{x}$ & $\mathrm{x}$ & & & $\mathrm{x}$ & $\mathrm{x}$ & & $\mathrm{x}$ \\
\hline & Lembadion lucens & $\mathrm{x}$ & $\mathrm{x}$ & $\mathrm{x}$ & & $\mathrm{x}$ & $\mathrm{x}$ & $\mathrm{x}$ & $\mathrm{x}$ \\
\hline & Undetermined & & $\mathrm{x}$ & $\mathrm{x}$ & $\mathrm{x}$ & $\mathrm{x}$ & $\mathrm{x}$ & $\mathrm{x}$ & $\mathrm{x}$ \\
\hline \multirow[t]{4}{*}{ Hypotrichia } & Aspidisca circada & $\mathrm{x}$ & $\mathrm{x}$ & $\mathrm{x}$ & $\mathrm{x}$ & $\mathrm{x}$ & $\mathrm{x}$ & $\mathrm{x}$ & $\mathrm{x}$ \\
\hline & Aspidisca lynceus & $\mathrm{x}$ & $\mathrm{x}$ & $\mathrm{x}$ & & $\mathrm{x}$ & $\mathrm{x}$ & $\mathrm{x}$ & $\mathrm{x}$ \\
\hline & Aspidisca sp. & $\mathrm{x}$ & $\mathrm{x}$ & $\mathrm{x}$ & $\mathrm{x}$ & $\mathrm{x}$ & $\mathrm{x}$ & $\mathrm{x}$ & $\mathrm{x}$ \\
\hline & Euplotes sp. & & $\mathrm{x}$ & & & $\mathrm{x}$ & & $\mathrm{x}$ & \\
\hline \multirow[t]{11}{*}{ Litostomatea } & Acineria incurvata & $\mathrm{x}$ & $\mathrm{x}$ & & & & & $\mathrm{x}$ & \\
\hline & Acineria sp. & & $\mathrm{x}$ & & & & $\mathrm{x}$ & $\mathrm{x}$ & $\mathrm{x}$ \\
\hline & Acineria uncinata & $\mathrm{x}$ & $\mathrm{x}$ & & & & & & \\
\hline & Amphileptus procerus & $\mathrm{x}$ & & & & & & & \\
\hline & Amphileptus sp. & & & & & & & $\mathrm{x}$ & \\
\hline & Litonotus alpestris & $\mathrm{x}$ & $\mathrm{x}$ & & & $\mathrm{x}$ & $\mathrm{x}$ & $\mathrm{x}$ & $\mathrm{x}$ \\
\hline & Litonotus crystallinus & & $\mathrm{x}$ & & & $\mathrm{x}$ & & & $\mathrm{x}$ \\
\hline & Litonotus cygnus & $\mathrm{x}$ & $\mathrm{x}$ & & $\mathrm{x}$ & & & $\mathrm{x}$ & \\
\hline & Litonotus lamella & $\mathrm{x}$ & $\mathrm{x}$ & & & $\mathrm{x}$ & $\mathrm{x}$ & $\mathrm{x}$ & $\mathrm{x}$ \\
\hline & Litonotus sp. & & & & & & & $\mathrm{x}$ & \\
\hline & Undetermined & $\mathrm{x}$ & $\mathrm{x}$ & $\mathrm{x}$ & $\mathrm{x}$ & $\mathrm{x}$ & $\mathrm{x}$ & $\mathrm{x}$ & $\mathrm{x}$ \\
\hline \multirow[t]{4}{*}{ Nassophorea } & Chilodontopsis depressa & $\mathrm{x}$ & $\mathrm{x}$ & & $\mathrm{x}$ & $\mathrm{x}$ & $\mathrm{x}$ & $\mathrm{x}$ & $\mathrm{x}$ \\
\hline & Microthorax pusillus & & $\mathrm{x}$ & & & & & & \\
\hline & Zosterodasys transversa & & & & & & & & $\mathrm{x}$ \\
\hline & Undetermined & $\mathrm{x}$ & $\mathrm{x}$ & $\mathrm{x}$ & $\mathrm{x}$ & $\mathrm{x}$ & $\mathrm{x}$ & $\mathrm{x}$ & $\mathrm{x}$ \\
\hline
\end{tabular}


Table A1 (continued)

\begin{tabular}{|c|c|c|c|c|c|c|c|c|c|}
\hline \multirow[t]{3}{*}{ Rank } & \multirow[t]{3}{*}{ Morphotypes } & \multirow{2}{*}{\multicolumn{2}{|c|}{ _ Pla1 }} & \multirow{2}{*}{\multicolumn{4}{|c|}{$\begin{array}{l}\text { Experiments and treatments - } \\
\text { Ben1_ }\end{array}$}} & \multirow{2}{*}{\multicolumn{2}{|c|}{$-\operatorname{Ben} 2$}} \\
\hline & & & & & & & & & \\
\hline & & $\begin{array}{l}\text { Pla } \\
\text { CON }\end{array}$ & $\begin{array}{l}\text { Pla } \\
\text { ENR }\end{array}$ & $\begin{array}{l}\text { Ben } \\
\text { DARK }\end{array}$ & $\begin{array}{l}\text { Ben } \\
\text { LIGHT }\end{array}$ & $\begin{array}{l}\text { Pla } \\
\text { CON }\end{array}$ & $\begin{array}{l}\text { Pla } \\
\text { ENR }\end{array}$ & $\begin{array}{l}\text { Ben } \\
\text { DARK }\end{array}$ & $\begin{array}{l}\text { Ben } \\
\text { LIGHT }\end{array}$ \\
\hline \multirow[t]{9}{*}{ Peritrichia } & Campanella umbellaria & & & & & & & $\mathrm{x}$ & $\mathrm{x}$ \\
\hline & Carchesium polypinum & & $\mathrm{x}$ & $\mathrm{x}$ & & $\mathrm{x}$ & $\mathrm{x}$ & $\mathrm{x}$ & $\mathrm{x}$ \\
\hline & Epistylis sp. & & & & $\mathrm{x}$ & $\mathrm{x}$ & & $\mathrm{x}$ & $\mathrm{x}$ \\
\hline & Vorticella aquadulcis-complex & $\mathrm{x}$ & $\mathrm{x}$ & & & & & & \\
\hline & Vorticella campanula & $\mathrm{x}$ & $\mathrm{x}$ & & & $\mathrm{x}$ & $\mathrm{x}$ & $\mathrm{x}$ & $\mathrm{x}$ \\
\hline & Vorticella picta & $\mathrm{x}$ & $\mathrm{x}$ & $\mathrm{x}$ & $\mathrm{x}$ & $\mathrm{x}$ & $\mathrm{x}$ & $\mathrm{x}$ & $\mathrm{x}$ \\
\hline & Vorticella sp. & $\mathrm{x}$ & $\mathrm{x}$ & $\mathrm{x}$ & $\mathrm{x}$ & $\mathrm{x}$ & $\mathrm{x}$ & $\mathrm{x}$ & $\mathrm{x}$ \\
\hline & Zoothamnium procerius & & $\mathrm{x}$ & & & $\mathrm{x}$ & $\mathrm{x}$ & $\mathrm{x}$ & $\mathrm{x}$ \\
\hline & Undetermined & $\mathrm{x}$ & $\mathrm{x}$ & $\mathrm{x}$ & $\mathrm{x}$ & $\mathrm{x}$ & $\mathrm{x}$ & $\mathrm{x}$ & $\mathrm{x}$ \\
\hline Prostomatea & Undetermined & & $\mathrm{x}$ & & & & & & \\
\hline \multirow[t]{4}{*}{ Scuticociliatia } & Cinetochilum margaritaceum & $\mathrm{x}$ & $\mathrm{x}$ & $\mathrm{x}$ & $\mathrm{x}$ & $\mathrm{x}$ & $\mathrm{x}$ & $\mathrm{x}$ & $\mathrm{x}$ \\
\hline & Cyclidium glaucoma & $\mathrm{x}$ & $\mathrm{x}$ & & & & & & \\
\hline & Uronema nigricans & $\mathrm{x}$ & & & & & & & \\
\hline & Undetermined & $\mathrm{x}$ & $\mathrm{x}$ & $\mathrm{x}$ & $\mathrm{x}$ & $\mathrm{x}$ & $\mathrm{x}$ & $\mathrm{x}$ & $\mathrm{x}$ \\
\hline \multirow[t]{6}{*}{ Stichotrichia } & Holosticha pullaster & $\mathrm{x}$ & $\mathrm{x}$ & $\mathrm{x}$ & $\mathrm{x}$ & $\mathrm{x}$ & $\mathrm{x}$ & $\mathrm{x}$ & $\mathrm{x}$ \\
\hline & Holosticha sp. & $\mathrm{x}$ & $\mathrm{x}$ & & & & & & \\
\hline & Oxytricha sp. & $\mathrm{x}$ & $\mathrm{x}$ & & & & & & \\
\hline & Stylonychia mytilus & $\mathrm{x}$ & $\mathrm{x}$ & & $\mathrm{x}$ & & $\mathrm{x}$ & & $\mathrm{x}$ \\
\hline & Undetermined & $\mathrm{x}$ & $\mathrm{x}$ & $\mathrm{x}$ & $\mathrm{x}$ & $\mathrm{x}$ & $\mathrm{x}$ & $\mathrm{x}$ & $\mathrm{x}$ \\
\hline & Uroleptus piscis & & $\mathrm{x}$ & & $\mathrm{x}$ & & & & $\mathrm{x}$ \\
\hline Suctoria & Undetermined & $\mathrm{x}$ & $\mathrm{x}$ & & & & & $\mathrm{x}$ & \\
\hline
\end{tabular}

Editorial responsibility: Hugh MacIntyre, Dauphin Island, Alabama, USA
Submitted: August 18, 2010; Accepted: March 2, 2011 Proofs received from author(s): May 23, 2011 